\title{
Cumulative IIIness Rating Scale for Geriatrics
}

National Cancer Institute

\section{Source}

National Cancer Institute. Cumulative IIIness Rating Scale for Geriatrics. NCI Thesaurus. Code C134826.

A clinical assessment tool designed to measure comorbidity in geriatric cancer patients. The tool grades comorbidity severity from 0-4 in 14 organ systems. 